\title{
Centralized Power Control Strategy for AC-DC Hybrid Micro-Grid System using Multi-converter Scheme
}

\author{
Mir Nahidul Ambia, Ahmed Al-Durra, and S.M.Muyeen \\ Electrical Engineering Department, The Petroleum Institute, P.O.Box 2533, Abu Dhabi, UAE \\ E-mail: mambia@pi.ac.ae
}

\begin{abstract}
In this paper, an ac-dc hybrid micro-grid system including a centralized power control scheme is proposed. Multiple ac-dc bidirectional converters connected in parallel are considered in the system instead of a single converter that connects ac and dc buses. The proposed control scheme is basically coordination of two modes-control of power through the converters and selection of converter units. The power through the converter is controlled because the load unbalance between ac and dc buses should be mitigated. Selection of converter units is also important because each small unit can deal partial amounts of power of the entire micro-grid system and therefore control of parallel operation of multiple converter units should be considered. If any converter fails to operate in the system then the alternate converters come into operation, so that the micro-grid system will not be totally disconnected and thus reliability of the system is ensured. This will also increase the efficiency of the system during low power transmission condition. The system operation is investigated under three different conditions to show the effectiveness of the proposed control scheme.
\end{abstract}

Keywords: Micro-Grid, Centralized, Multi-converters, wind power generation system, PV system.

\section{INTRODUCTION}

In the last few decades, the demand for electricity is growing at a steady pace. According to the U.S. Energy Information Administration (EIA) [1], the electricity generated from coal in the U.S. increased by $64 \%$ between 1980 and 2001 and is projected to be $45 \%$ higher in 2025 than in 2001. This ever increasing demand is taking present power scenarios towards Distributed Generation in which smaller power sources are used to meet the customers demand. The small modular generations like wind, photovoltaic, fuel cells, diesel and batteries are internally connected to the distribution systems which form an independent power system interface as Micro-Grid [2-3].

It is even more suitable for isolated, standalone or small islands where renewable energy can be the only source. In recent years, a growing interest for micro-grids has been observed. The micro-grid is capable of operating with only a small power exchange with the power system and can be disconnected from the main grid. Micro-grid operates in mainly two modes; grid-tied and islanded. In grid-tied mode, the micro-grid is connected with the utility grid and the loads consume power both from the renewable energy sources and the utility grid depending on their requirements. If the required power absorbed by the loads is greater than generations of the micro-grid then utility grid injects power in the system. On the other hand, in islanded mode, the utility grid is disconnected from the micro-grid and it runs independently in the system and delivers power to the loads [4].

In this paper, the attention is focused on the reliability and efficiency enhancement of the micro-grid. From the above consideration it is clear that reliability of micro-grid is of highest importance from the customers' point of view. Reliability and continuity of supply ensure customers' satisfaction. In this paper, scheme for the reliability enhancement of the hybrid micro-grid system is proposed using parallel operation of multiple power converter units. It should be noted that parallel operation of converter units can increase the efficiency of the system especially when the system runs at low power. A centralized power control scheme is developed which is another salient feature of this study.

At this scope, in the first section different dynamic system modeling for the hybrid ac-dc micro-grid system is discussed. In the second section details of proposed scheme are given which include system configuration and load management. The third section demonstrates the proposed control strategy focusing on reliability enhancement. In the fourth section, simulation results are shown to achieve the targets of the control scheme for different operating conditions. Finally, the conclusions are drawn in the last section.

\section{DYNAMIC SYSTEM ModelinG}

\section{A. Wind turbine modeling}

Wind turbine captures kinetic energy from the wind and converts it into electrical energy. The wind turbine output torque and extracted power from the wind turbine can be expressed by [5-8] below equations.

$$
\begin{aligned}
& T_{m}=\frac{1}{2} \cdot \rho C(\lambda) \pi R^{3} V_{W}{ }^{2}[N M] \\
& P_{m}=\frac{1}{2} \cdot \rho C_{P}(\lambda, \beta) \pi R^{2} V_{W}{ }^{3}[W]
\end{aligned}
$$

Where $\rho$ is the air density, $\mathrm{R}$ is the radius of the turbine, $\mathrm{V}_{\mathrm{W}}$ is the wind speed, $C_{P}(\lambda, \beta)$ is the power coefficient given by 
$C_{P}(\lambda, \beta)=\frac{1}{2} \cdot\left(\Gamma-0.02 \beta^{2}-5.6\right) e^{-0.17 \Gamma}$

Where, $\Gamma=\frac{R(3600)}{\lambda(1609)}$ and $\lambda=\frac{\omega_{m} R}{V_{w}} \quad$ is the tip speed ratio.

The relationship between $C_{t}$ and $C_{p}$ is

$$
C_{t}(\lambda)=\frac{C_{P}(\lambda)}{\lambda}
$$

\section{B. Solar panel modeling}

A solar model is the basic element of each photovoltaic system which consists of a diode, a current source, a series resistance and a parallel resistance. The current source produces the photo current which is a function of the incident solar cell radiation and temperature. p-n junction of a solar cell is represented by the diode. The photovoltaic cell current equation can be expressed as [9]

$I_{P V}=n_{P} I_{P h}-n_{P} I_{r s}\left[e^{\left(\frac{q V_{d c}}{K T_{C} A n_{S}}\right)}-1\right]$

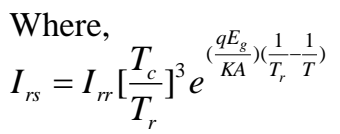

$I_{p h}=0.01\left[I_{s c r}+K_{v}\left(T_{c}-T_{r}\right)\right] s$

Where, $n_{S}$ and $n_{P}$ are the number of cells connected in series and parallel respectively. $\mathrm{I}_{\mathrm{ph}}$ is the photo current, $\mathrm{I}_{\mathrm{rs}}$ and $\mathrm{I}_{\mathrm{rr}}$ are reverse saturation current at $\mathrm{T}$ and $\mathrm{T}_{\mathrm{r}}$. $\mathrm{T}$ is cell temperature and $T_{r}$ is reference temperature. $I_{s c r}$ is the cell short circuit current at $T_{r}$. $S$ stands for irradiance in mw/cm ${ }^{2}$. $K$ is Boltzmann constant, $K_{v}$ is the short circuit temperature coefficient at $\mathrm{I}_{\mathrm{scr}}$ and $\mathrm{q}$ is charge of electron. A is the identity factor. $\mathrm{I}_{\mathrm{PV}}$ is current from the photovoltaic cell.

\section{Fuel cell modeling}

Fuel cells are electrochemical devices which convert the chemical energy of a reaction into electrical energy. A fuel cell basically consists of an electrolyte layer (Ion conductor) in between a porous anode and cathode. Electric current is produced from the electrochemical reactions at the electrode, when gaseous fuel is injected to the anode and oxidant is fed to cathode [10-11].

\section{Energy storage system}

Energy storage is a device that stores energy and performs useful operation when by discharging it to the system. The energy storage system (ESS) nowadays is closely consociated with renewable energy sources such as photovoltaic or wind power applications even in micro-grids. In case of excessive power generation, ESS can store the energy and can inject power to the system when the demand is greater or the generation is depleted.

In the proposed micro-grid system, ESS is considered to be connected at the terminal of fixed speed wind turbine generator system which ensures constant power delivery by absorbing the fluctuating quantity of the wind power as shown in Fig. 1. The ESS charges the first half cycle of the variable power and then discharges it at the next cycle so that the constant power can be delivered to the power grid [12].

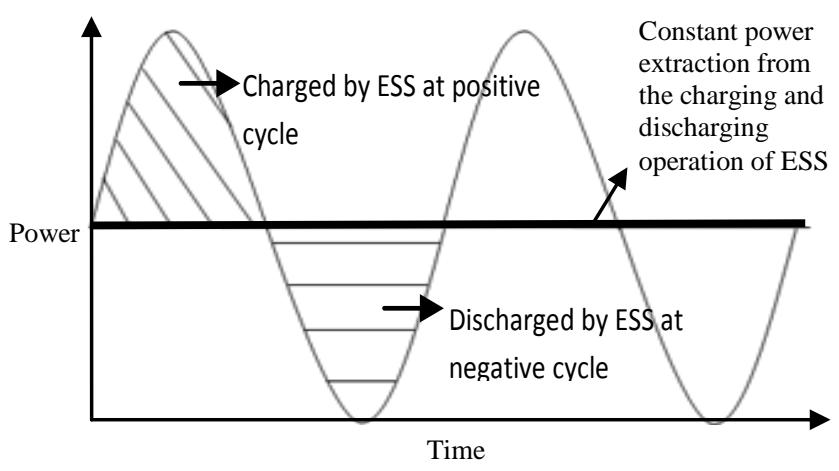

Fig.1. Wind power smoothing operation by ESS

\section{PROPOSED MICRO-GRID SYSTEM}

\section{A. System configuration}

A hybrid micro-grid system has been proposed and shown in Fig. 2 which consists of AC grid on the left and DC grid on the right side. The AC and DC buses have corresponding sources, loads, and energy storage systems. An Induction generator driven by fixed speed wind turbine is connected at the ac side as ac source and Solar cell, fuel cells are connected at the dc side as dc source [13]. Battery as an energy storage system has been plugged in both sides.

A utility grid is linked with the ac bus via a transformer after first transmission line. The solar cell is connected with the dc bus via DC-DC boost converter so that maximum power can be extracted from solar panel. Fuel cell and energy storage system at the dc bus are also connected by DC-DC converter. Energy storage system is linked on the ac side right at the terminal of the induction generator so that the constant delivery of power can be ensured. Capacitor bank is used to maintain unity power factor operation at the rated wind speed.

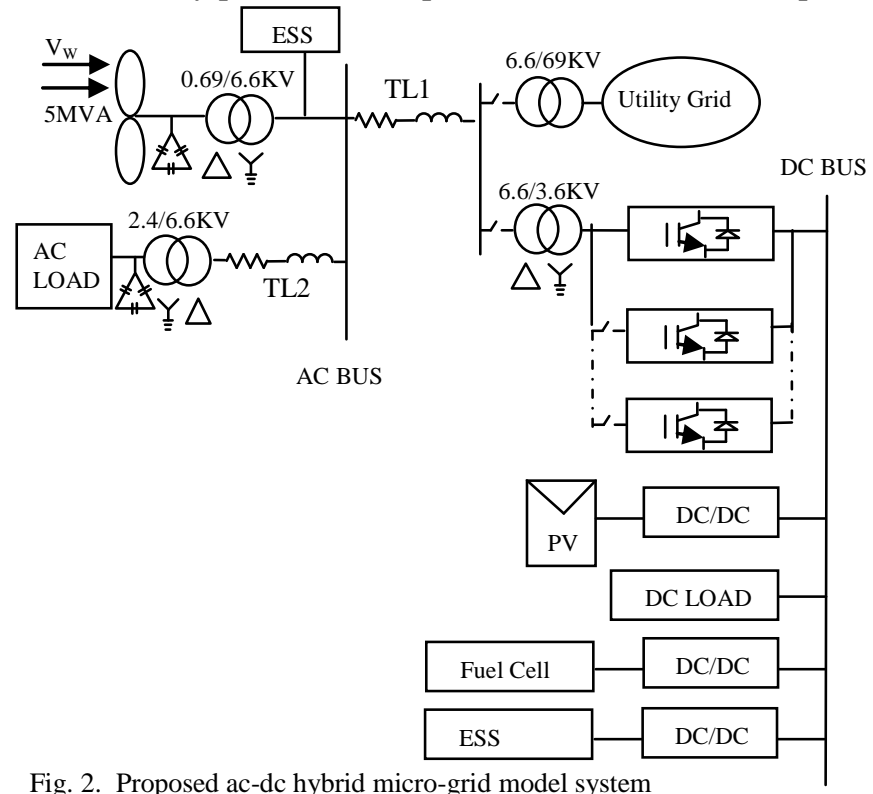

Fig. 2. Proposed ac-dc hybrid micro-grid model system 
The reactive power compensation at the wind generator terminal during low wind speed condition can be handled by the bidirectional AC-DC converters or using ESS. The parameters of the proposed micro-grid system and induction generator are shown in Table I. Multiple bi-directional ACDC converters connected in parallel are linking ac and buses. The converter ensures the power load management of the micro-grid system and multiple parallel connections of the converters which enhance the reliability of the system.

The induction generator delivers $5 \mathrm{MW}$ and solar cell generates 0.5 MW amount of power [14]. The total generation is distributed to the ac and dc loads through parallel bi-directional ac-dc converters. During low load conditions one converter is supposed to be in operation. If the dc load increases or the power through the converter crosses its rated capacity then another converter will automatically turn on and thus the efficiency of the system will eventually increase because small converter units of the multi-converter system are operating rated or close to rated condition. Another important point to be mentioned is, if any converter in the micro-grid system fails then the alternate converter will be able to transmit the power up to certain levels resulting in establishing the reliability of the overall system.

\section{B. Load Management}

Load unbalance is one of the prime issues to be focused on in ac and dc bus based hybrid micro-grid systems. In the proposed model, centralized power control strategy has been applied which can compensate the load unbalance in ac and dc busses of the system. In the micro-grid system, especially while operating in isolated mode, load management is very important because power generated by renewable and conventional sources that are delivered to ac or dc bus should be absorbed by the loads connected to those ac and dc busses to maintain system stability in terms of voltage and frequency. As the loads in the micro-grid system may vary or some portions of the loads may get lost by system failure, various types of distribution of generated power should be considered in the centralized control scheme to adapt with load unbalance occurrences.

In this ac-dc bus based hybrid micro-grid system load management is performed in an efficient way concentrating on the power converter between ac and dc busses considering different load and generation scenarios. Fig. 3 is a flowchart of the centralized control scheme for the proposed multiconverter based ac-dc micro-grid system. If the total generation is exactly equal with the loads then all power will be distributed to the load but if the generation exceeds the loads demand, excess power will be delivered to the grid. On the other hand, if the total generation is less than the total load demand then power will be taken from the grid. In the case of increasing load demand at dc bus which cannot be supplied by the renewable power generation system connected to the dc-bus, load management will be handled by controlling power transfer by the multi-converter system or vice versa. Depending on the total power transfer required from ac to dc bus or vice versa small units of multi-converter systems will be switched on or off, helping to increase the efficiency by running each small unit close to rated condition.

\section{Multi-Converter Based Centralized Power CONTROL STRATEGY}

Centralized power control strategy based on parallel connected multiple power converters is proposed in this study and the control scheme is briefly shown in Fig. 3. Central processing unit (CPU) performs the load management precisely and power transfer in ac to dc bus or vice versa are controlled by generating power command for individual units of the multi-converter system. Number of active converter unit is also determined by CPU and based on that enable and disable signals are sent to all units of multi-converter system as shown in Fig. 3. Fig. 4 shows the control block diagram of

TABLE II

LOAD MANAGEMENT OF MICRO-GRID WITH DIFFERENT CASES

\begin{tabular}{|l|l|}
\hline \multicolumn{1}{|c|}{ Parameters } & \multicolumn{1}{c|}{ Value } \\
\hline Base voltage of converter & $3.6 \mathrm{kv} \mathrm{V}$ LL \\
\hline Base current of converter & $0.40093 \mathrm{~A}$ \\
\hline Resistance (TL1) & $0.26368 \mathrm{ohm}$ \\
\hline Inductance (TL1) & $0.0004326 \mathrm{H}$ \\
\hline Length (TL1) & $2.06 \mathrm{~km}$ \\
\hline Resistance (TL2) & $0.013312 \mathrm{ohm}$ \\
\hline Inductance (TL2) & $0.0002184 \mathrm{H}$ \\
\hline Length (TL2) & $104 \mathrm{~m}$ \\
\hline AC generation & $5 \mathrm{MW}$ \\
\hline DC generation & $0.5 \mathrm{MW}$ \\
\hline PWM carrier frequency & $1000 \mathrm{~Hz}$ \\
\hline AC loads & $1.5 \sim 3 \mathrm{MW}$ \\
\hline DC loads & $3 \sim 3.5 \mathrm{MW}$ \\
\hline DC link voltage & $6.6 \mathrm{kv}$ \\
\hline DC link capacitance & $100000 \mu \mathrm{F}$ \\
\hline
\end{tabular}

\begin{tabular}{|c|c|c|c|c|c|c|c|c|c|}
\hline \multirow{5}{*}{$\underset{\tilde{z}}{\ddot{\mho}}-$} & \multirow{2}{*}{$\begin{array}{c}\mathrm{AC} / \mathrm{D} \\
\mathrm{C}\end{array}$} & \multirow[t]{2}{*}{ Generations } & \multirow[t]{2}{*}{ Grid } & \multicolumn{3}{|c|}{ Loads } & \multicolumn{2}{|c|}{ Converters } & \multirow{2}{*}{$\begin{array}{l}\text { Total } \\
\text { Loads } \\
\text { (MW) }\end{array}$} \\
\hline & & & & L1 & L2 & L3 & PC1 & PC2 & \\
\hline & $\mathrm{AC}$ & 5 & & 1.5 & 1.5 & & 2 & 0 & 3 \\
\hline & $\mathrm{DC}$ & 0.5 & & 2 & 0.5 & & & & 2.5 \\
\hline & Total & 5.5 & & & & & & & 5.5 \\
\hline \multirow{3}{*}{ 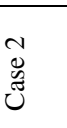 } & $\mathrm{AC}$ & 5 & 1.5 & 1.5 & 1.5 & & 1.75 & 1.75 & 3 \\
\hline & $\mathrm{DC}$ & 0.5 & & 2 & 0.5 & 1.5 & & & 4 \\
\hline & Total & 5.5 & & 1.5 & & & & & 7 \\
\hline \multirow{3}{*}{ 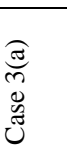 } & $\mathrm{AC}$ & 5 & & 1.5 & & & 1.75 & 1.75 & 1.5 \\
\hline & $\overline{\mathrm{DC}}$ & 0.5 & & 2 & 0.5 & 1.5 & & & 4 \\
\hline & Total & 5.5 & & & & & & & 5.5 \\
\hline \multirow{3}{*}{ : } & $\overline{\mathrm{AC}}$ & 5 & & 1.5 & 1.5 & & 2 & 0 & 3 \\
\hline & $\overline{D C}$ & 0.5 & & 2 & 0.5 & & & & 2.5 \\
\hline & Total & 5.5 & & & & & & & 5.5 \\
\hline
\end{tabular}



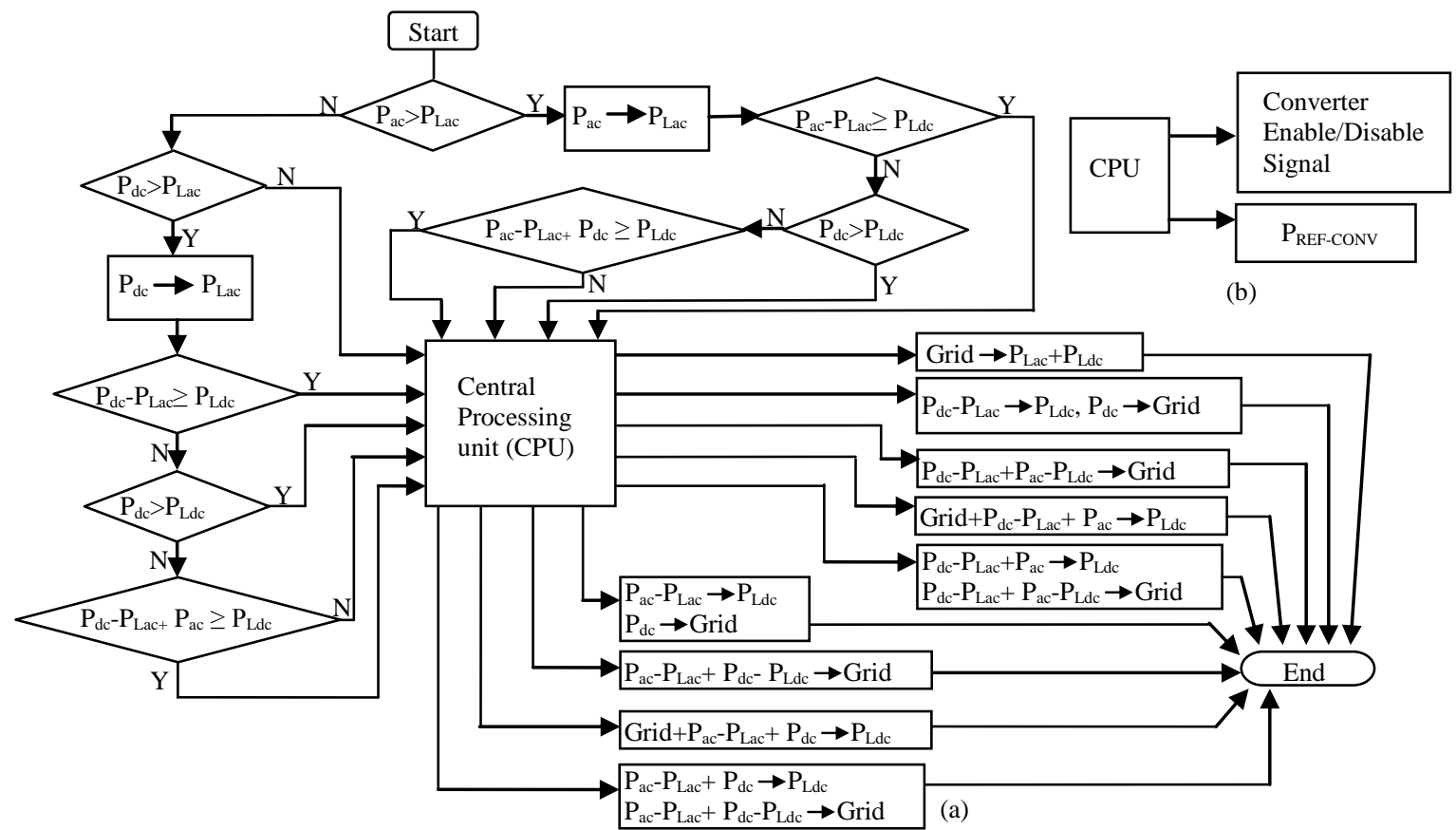

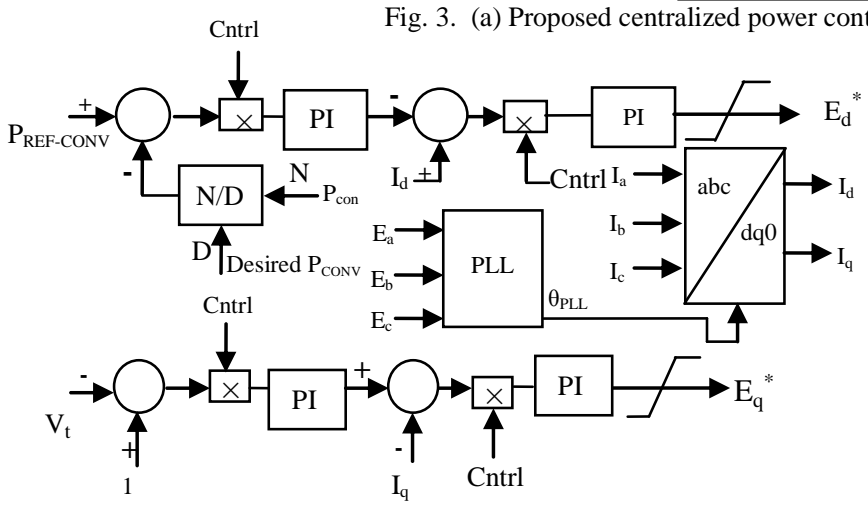

Fig. 4. Real and reactive power controller of converters

individual small converter unit, where PLL provides the angle $\theta_{P L L}$ for the abc-to-dq0 (and dq0-to-abc) transformation. The $\mathrm{d}$-axis current controls the real power and, while the q-axis current controls the reactive power of the converter. After a dq0-to-abc transformation, $E_{q}{ }^{*}$ and $E_{d}{ }^{*}$ are sent to the PWM signal generator. Finally three phase reference signal is obtained and used to generate switching pulses for the power converter.

\section{Simulation Results}

Simulation analysis for the ac-dc hybrid micro-grid system are performed for three cases in PSCAD/EMTDC environment which depicts the impact of parallel multiple converters and centralized power control scheme, cases are summarized in Table II. As detailed switching model is considered in the simulation for the sake of preciseness only two parallel connected converters are considered in the system to speed up the simulation. Rated power of each converter unit is $2.5 \mathrm{MW}$. For cases 1 and $230 \mathrm{sec}$ simulation results are presented and for case 3 simulation time is $50 \mathrm{sec}$.

In case 1 , total $\mathrm{dc}$ generation is considered lower than $\mathrm{dc}$ load connected to the dc bus and therefore central processing unit (CPU) forces power from ac bus to dc bus through multi- converter unit. However, as total power required to be transmitted from ac bus to dc bus is lower than the rated power of single converter unit, second converter is switched off by CPU. Fig. 5 shows the generations, load, and power through the multi-converter system. In case 2, one additional dc load of 1.5 MW came to operation at a sudden. As total loads exceed the total generations of micro-grid system, the system works on grid connected mode to supply power to the newly added load. Table II shows that $3.5 \mathrm{MW}$ power is required to be transmitted through the multi-converter system to manage the load demand and hence both converters are set activated by CPU as single unit exceeds its rated capacity of 2.5 MW. The real power responses are shown in Fig. 6 for this case.

In case 3 , the stability and reliability enhancements of the micro-grid system are depicted (Fig. 7) when the converter 2 is tripped either by an internal fault or due to maintenance purpose. System was operating in isolated mode until $10 \mathrm{sec}$, while the two converters were set activated. Up to 10 seconds, ac load was $1.5 \mathrm{MW}$ and total dc loads were $4 \mathrm{MW}$ and power glided by the converters was $1.75 \mathrm{MW}$ as shown in case 3(a) of Table II. When the converter 2 is lost at $10 \mathrm{sec}$, an ac dump load of $1.5 \mathrm{MW}$ is added at ac bus so that power transmitted through another converter does not exceed the rated power $2.5 \mathrm{MW}$. Dc load 3 of $1.5 \mathrm{MW}$ will be forcefully disconnected from the system in order to balance the power flow as can be seen from Fig. 7a. Using centralized control scheme power through the converter is kept constant around $2 \mathrm{MW}$ as shown in Fig. $7 \mathrm{~b}$, which changes from the initial power of $1.75 \mathrm{MW}$ when two converters were working. Instead of using dump load in ac bus that power can also be sent to the main grid. Total power extracted from the ac and dc sources are shown in Fig. 7c. Terminal voltage in ac bus can return back shortly to its pre-disturbance level (Fig. 7d) and the voltage dip is not much under the proposed control 
scheme. DC voltages for converter $1 \& 2$ are shown together in Fig. 7e. Fig. 7 reflects that in spite of sudden loss of one converter in the system; the micro-grid system is still capable of delivering power to the loads, establishing enhanced stability and reliability. Failure of any converter does not affect the system in that sense.

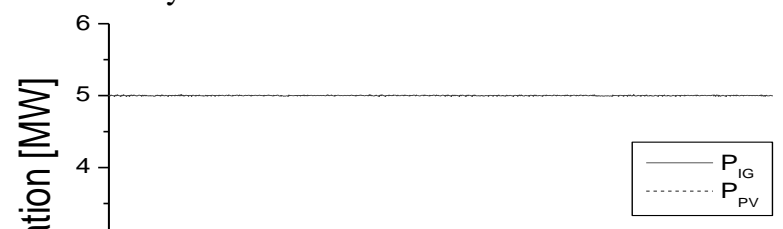

$$
0 \underset{0}{+}
$$
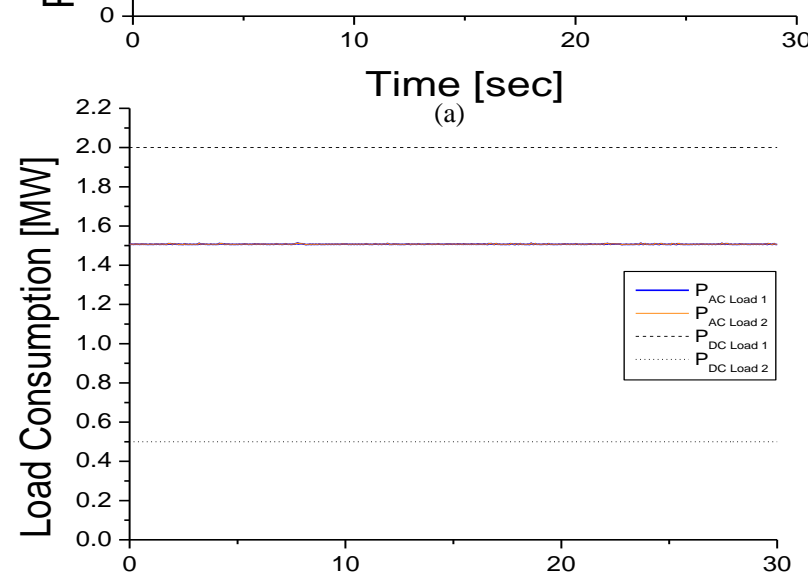

(a)

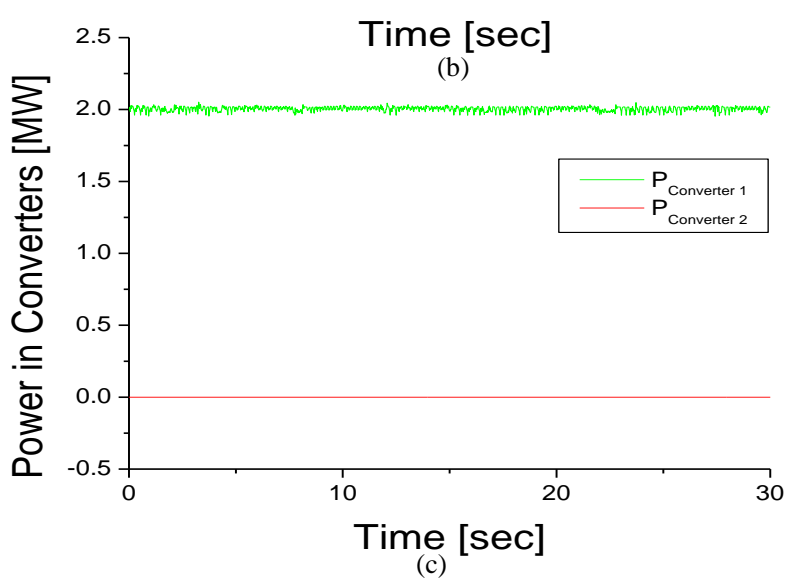

Fig. 5. System responses in Micro-grid system for case 1 (a) Power generations (b) Load consumptions (c) Power through converters

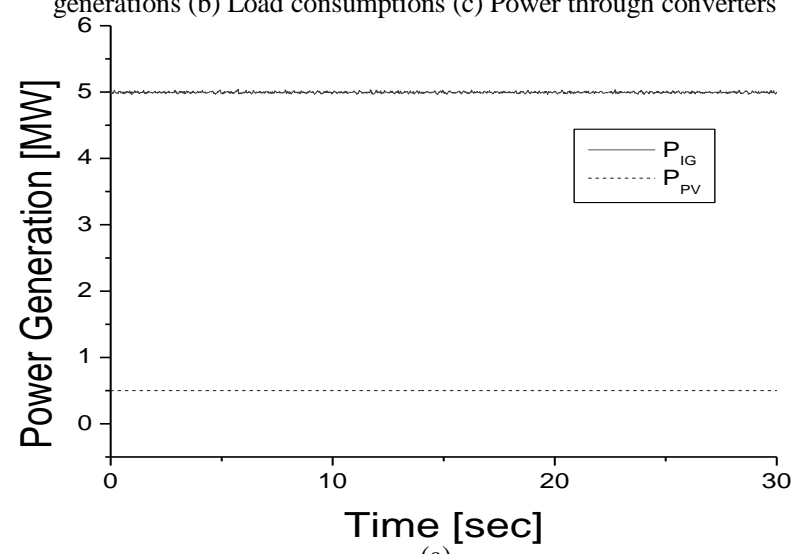

(a)
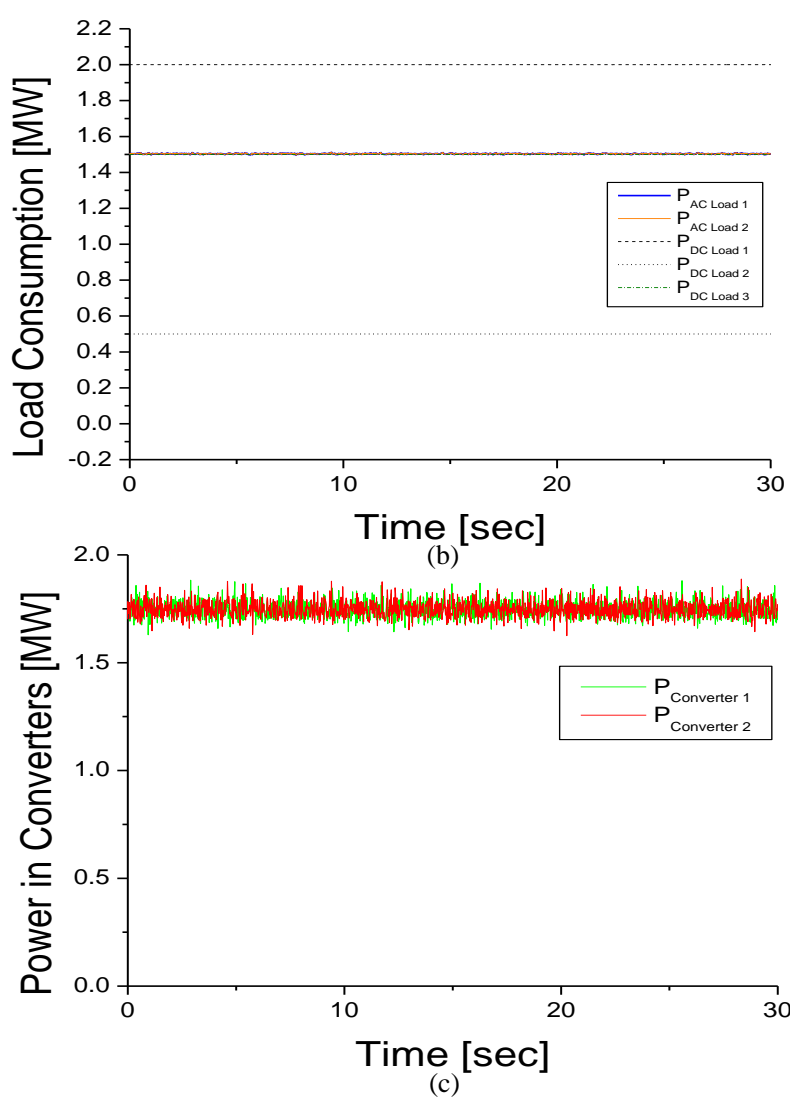

Fig. 6. System responses in Micro-grid system for case 2 (a) Power generations (b) Load consumptions (c) Power through converters while an extra dc load is being added with case 1 and utility grid delivers power in the system.

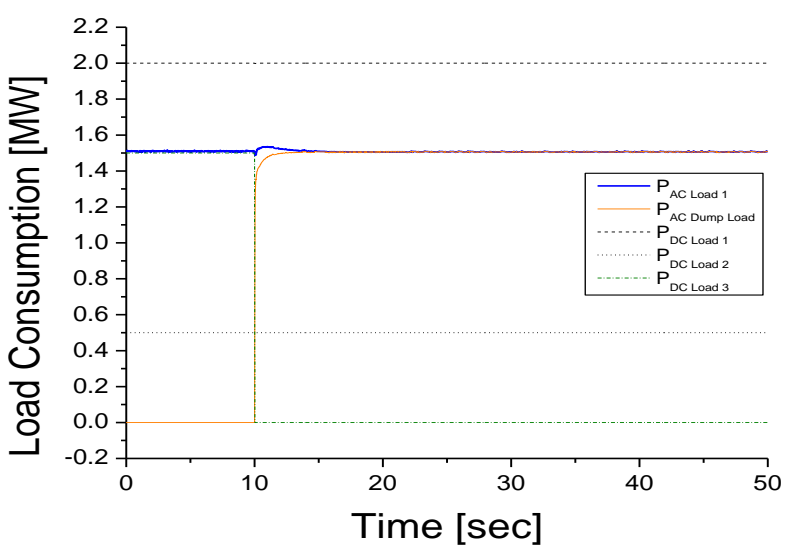

(a)

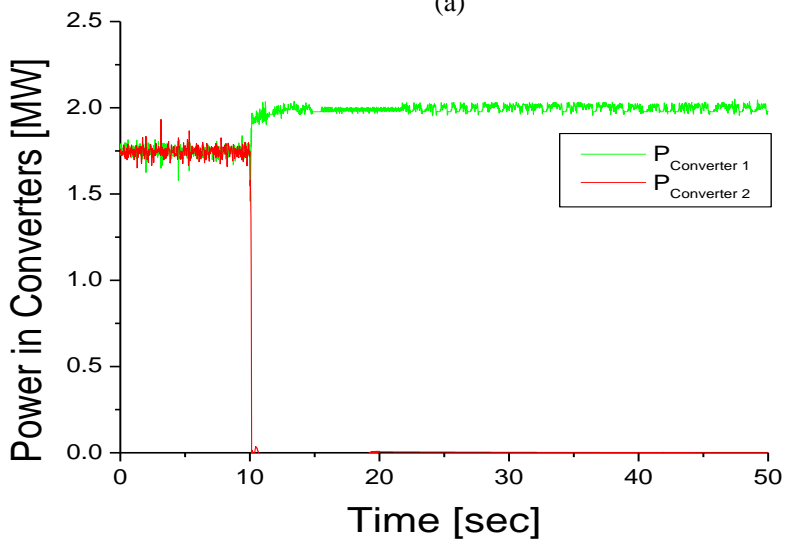

(b) 


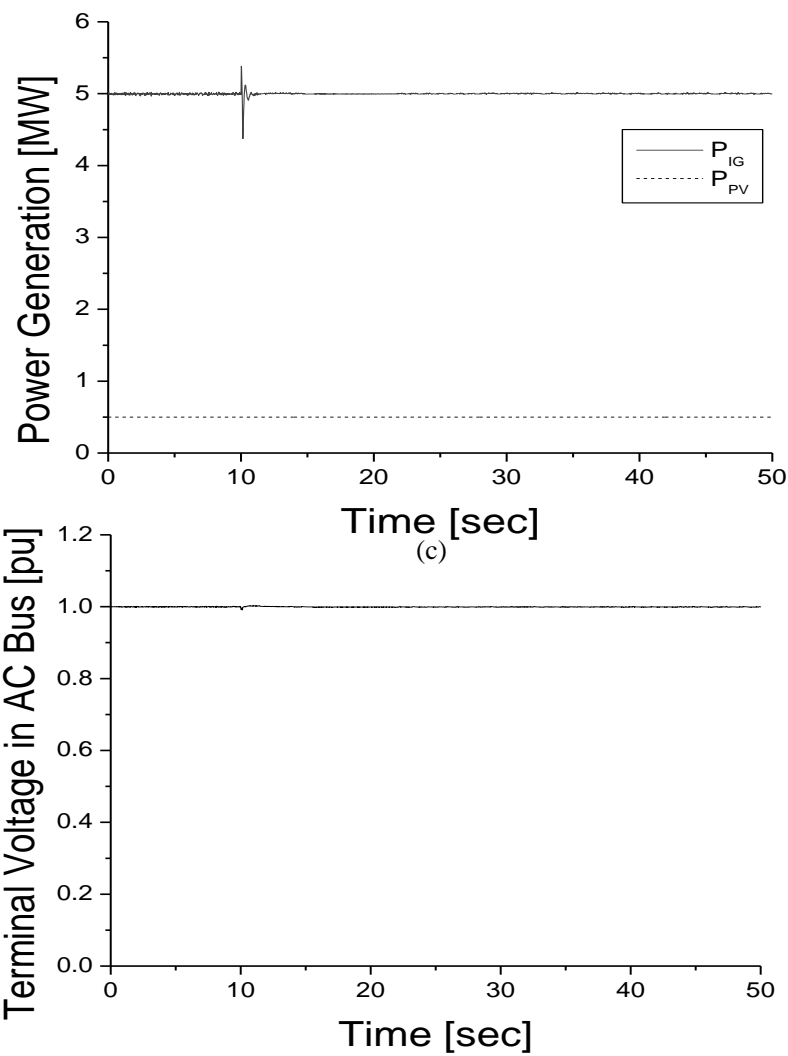

(d)

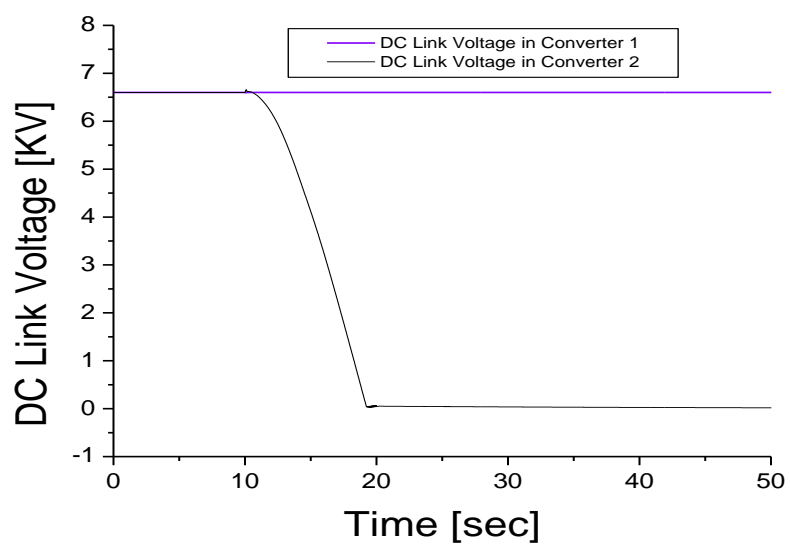

(e)

Fig. 7. System responses in Micro-grid system for case 3 where the converter 2 is suddenly lost at $t=10$ s (a) Load consumptions (b) Power through converters (c) Power generations (d) Terminal voltage at ac bus (e) DC link voltage in both converters.

\section{CONCLUSION}

The ac-dc based hybrid micro-grid system has been proposed with parallel connected converters and centralized power control scheme. The effectiveness of the proposed control scheme is verified by simulation analysis for different load scenarios which reflect the stability and reliability enhancement of the system. If power through individual converter unit of multi-converter system crosses its rated value, central processing unit enables operation of other units based on the amount of total power required to be transmitted. In this way, it is possible to operate an individual small unit close to rated condition that eventually increases the system efficiency. Even though a converter is lost all of a sudden, the power transmission through multi-converter system can be controlled using other converter units, load unbalance can be mitigated and reliability of the micro-grid can also be ensured. It is concluded that the central processing unit performs the load management of hybrid ac-dc based microgrid system in a precise way and same time augments the reliability and stability of the overall system.

\section{REFERENCES}

[1] N. K. Ardeshna and B. H. Chowdhury, "Optimizing Micro-grid Operations in the Presence of Wind Generation," Power Symposium, NAPS'08, 28-30 Sept. 2008.

[2] Anne-Marie Borbely and Jan F. Kreider, Distributed Generation: Power Paradigm for the New Millennium; CRC Press., 2001.

[3] R. H. Lasseter, "MicroGrids," PES Winter Meeting, vol. 1, pp. 305-308, 2002.

[4] A. Burgio, D.Menniti and N. Sorrentino, "The reliability studies of a novel integrated configuration for micro-grids," International conference on Electric Utility Deregulation and Restructuring and Power Technologies, pp-2634-2639, 6-9 April 2008.

[5] K.E. Okedu, S.M. Muyeen, R. Takahashi, and J. Tamura, "Comparative Study between Two Protection Schemes for DFIG-based Wind Generator," Proceedings of International Conference on Electrical Machines and Systems, pp. 62-67, 10-13 Oct. 2010.

[6] R. Takahashi, J. Tamura, M. Futami, M. Kimura and K. Idle, "A New Control Method for Wind Energy Conversion System Using Double Fed Synchronous Generators," IEEJ Trans. Power and Energy, Vol.126, No.2, pp.225-235, 2006 (in Japanese).

[7] T. Sun, Z. Chen and F. Blaabjerg, "Transient Stability of DFIG Wind Turbines at an External Short Circuit Fault," Wind Energy Journal, Vol. 8, pp. 345-360, 2005.

[8] R. D. Fernandez, P.E. Battaiotto, and R. J. Mantz, "Wind Farm NonLinear Control for Damping Electromechanical Oscillations of Power Systems," Renewable Energy, Vol. 33, pp. 2258-2265, 2008.

[9] G. Vachtsevanos and K. Kalaitzakis, "A Hybrid Photovoltaic Simulator for Utility Interactive Studies,” IEE Trans. Energy Conversion, Vol. EC-2, No. 2, pp. 227-231, June 1987.

[10] M.J Khan and M. T. Iqbal, "Dynamic Modeling and Simulation of a Small Wind-Fuel Cell Hybrid Energy System," Renewable Energy, pp. 421-439,2005.

[11] T. Tsao, P. Chen and H. Chen, "Dynamic Modeling and Simulation of Hybrid Power Systems Based on Renewable Energy", International conference on Energy and Environment Technology, pp. 602-605, Oct. 2009.

[12] S. M. Muyeen, J. Tamura, and T. Murata, "Stability Augmentation of a Grid-connected Wind Farm," Springer-Verlag London, ISBN 978-184800-315-6, October 2008.

[13] X. Liu, P. Wang and P. C. Loh, "A Hybrid AC/DC Micro-Grid," IPEC, 2010, pp. 746-751, 27-29 Oct. 2010.

[14] F. Katiraei, M. R. Iravani and P.W. Lehn, "Micro-Grid Autonomous Operation During and Subsequent to Islanding Process," IEEE Trans. On Power Delivery, Vol. 20, No 1, January 2005.

[15] “PSCAD/EMTDC Manual," Manitoba HVDC Research Center, 1994. 